\title{
Studies on Seasonal Incidence of Sorghum Shoot Fly, Atherigona soccata (Rondani) and Stem Borer, Chilo partellus (Swinhoe), in Relation to Abiotic Factor
}

\author{
Nirvesh Singh*, Rajendra Singh and Kaushlendra Kumar
}

Department of Entomology, Sardar Vallabhbhai Patel University of Agriculture and Technology, Meerut-250110 (U.P.) India

*Corresponding author

\begin{tabular}{|c|c|}
\hline & A B S T R A C T \\
\hline Keywords & \multirow{4}{*}{$\begin{array}{l}\text { The field experiment was conducted during Kharif- } 2012 \text { at Crop Research Centre (Chirori } \\
\text { farm) of Sardar Vallabhbhai Patel University of Agriculture and Technology, Meerut } \\
\text { (U.P.) to characterize relationship of various meteorological parameters with sorghum } \\
\text { shoot fly and stem borer incidence. In the experiment dead hearts of shoot fly start } \\
\text { increasing observed first during in } 16^{\text {th }} \text { to } 22^{\text {th }} \text { July ( } 29^{\text {th }} \text { standard weeks). And maximum } \\
\text { dead hearts recorded during crop season from } 13^{\text {th }} \text { to } 19^{\text {th }} \text { August ( } 33^{\text {th }} \text { standard week). In } \\
\text { the experiment dead hearts of stem borer start increasing from } 23^{\text {th }} \text { to } 29^{\text {th }} \text { July ( } 30^{\text {th }} \\
\text { standard weeks) and maximum dead hearts of Chilo partellus (Rondani) were recorded } \\
\text { during crop season from } 20^{\text {th }} \text { to } 26^{\text {th }} \text { August }\left(34^{\text {th }} \text { standard weeks). The shoot fly and stem }\right. \\
\text { borer incidence in the form of dead hearts was correlated with the meteorological } \\
\text { parameters corresponding to the period of observations. }\end{array}$} \\
\hline $\begin{array}{l}\text { Sorghum germplasm, } \\
\text { Relative humidity, } \\
\text { Temperature, Rainfall, } \\
\text { Shoot fly, Stem borer }\end{array}$ & \\
\hline Article Info & \\
\hline $\begin{array}{l}\text { Accepted: } \\
\text { 06 May } 2018 \\
\text { Available Online: } \\
\text { 10 June } 2018\end{array}$ & \\
\hline
\end{tabular}

\section{Introduction}

Sorghum, Sorghum bicolour (L. Moench) is a premier crop of the semi-arid tropics and a major staple food in several parts of the world. It is a dry land crop grown in kharif and rabi seasons for the utility as food, feed, forage and industrial raw material. Grown as human food (Africa and India) or animal feed and fodder on about 50 million hectares annually (Sharma et al., 1992). Sorghum crop is being attacked by nearly 150 insect species causing an annual loss of over $\$ 1$ billion in the Semi-Arid Tropics (ICRISAT, 1992) and the most damaging species are Chilo partellus, Busseola fusa and Eldana saccharina (Songa et al., 2001). De Groote et al., (2003) found that all stem borer species caused average annual losses of $13.5 \%$, valued at US\$ 80 million. In India, a number of stem borer species have been reported as serious pests of sorghum crop of which spotted stem borer, Chilo partellus (Swinhoe) (Lepidoptera: Pyralidae) is important (Jotwani et al., 1971).

Host-plant resistance is one of the most effective means of pest management in sorghum. It is compatible with other methods of pest control, does not involve extra cost for the farmers, and is environment-friendly. There are over 36,700 germplasm accessions of sorghum in the gene bank at the 
International Crops Research Institute for the Semi -Arid Tropics (ICRISAT), Patancheru, India, which serves as a global repository of the sorghum germplasm. The problems has become more acute with the introduction of shoot fly of exotic dwarf, which are highly susceptible to shoot fly (Rai and Jotwani, 1977) estimated the losses in grain yield of sorghum due to this pest to be $13-20 \%$. Silica deposition and abundance of sclerenchymatous cells in the leaf sheath (Ponnaiya, 1951), trichomes on the abaxial surface (Maiti and Bidinger, 1979), glossy leaves (Agrawal and House, 1982) and early seedling vigour (Jain and Bhatnagar, 1962; Blum, 1969) are reported to be the factors responsible for primary mechanism of shoot fly resistance. The two key pest, viz., shoot fly, Atherigona soccata (Rondani) and stem borer, Chilo partellus (Swinhoe), being internal feeders, most serious problems in achieving the targeted yield (Prem Kishore, 2001a) in northern part of the country. The role of environmental factors affecting these variations has also been described.

\section{Materials and Methods}

Screening of 27 germplasm of sorghum obtained from ICRISAT was undertaken field condition at Crop Research Centre (Chirori farm) of Sardar Vallabhbhai Patel University of Agriculture and Technology, Meerut (U.P.) during Kharif- 2012. Experiments were laid out in randomised block design with three replication, the row length being $3 \mathrm{~m}$. Row to row distance was $30 \mathrm{~cm}$ and plant to distance $15 \mathrm{~cm}$. The healthy seeds of sorghum were sown manually at the depth of $3-4 \mathrm{~cm}$. Recommended agronomic practices were followed for raising the fodder crop.

For the study of pest incidence observation were recorded on shoot infestation by sorghum shoot fly, Ahherigona soccata and stem borer, Chilo partellus at weekly interval throughout the growing season of the crop and randomly selected twenty plants in the field. The Dead shoots caused by this pest were counted in each entry from the first appearance, while damaged and healthy slant were counted at each observation (weekly). Damaged per cent on shoot fly and stem borer was calculated by recording the number of total and infested shoot. In general the early sowing crop escaped the shoot fly attack. Interlard Fishmeal Technique (Taneja and Leusschner, 1985) was used in addition to late sowing in Kharif season in order to ensure high shoot fly incidence. Kamatar et al., (2001a) reported that shoot fly incidence varied with season and resistance was relative to shoot fly density. The averages of the observations new sources of resistance to shoot fly and stem borer displayed in tables 1 and 2.

\section{Results and Discussion}

\section{Seasonal incidence of shoot fly}

The data recorded on dead hearts of shoot fly during Kharif-2012 have been presented in the Table 1 and Figure 1. It is evident that the activity of pest population throughout the growing season. Pest population (2.29\%) observed first during in $29^{\text {th }}$ standard week (July, 16-22) when the maximum and minimum temperature 35.14 and $28.00^{\circ} \mathrm{C}$, respectively, relative humidity 55.99 per cent and rainfall $0.00 \mathrm{~mm}$ were recorded, when the age of the crop was 8 days.

The dead hearts increased and reached maximum $(28 \%)$ in $33^{\text {th }}$ standard week (Aug, 13-19) when the maximum and minimum temperature 31.57 and $26.50^{\circ} \mathrm{C}$ respectively, relative humidity 67.24 per cent and rainfall $0.00 \mathrm{~mm}$. Maggot feeds on the growing tip causing wilting of leaf and later drying of central leaf giving a typical symptom of "dead heart". The damaged plants produce side tillers which again are infested (Fig. 2). 
Table.1 Seasonal incidence of shoot fly, Atherigona soccata (Rondani)

\begin{tabular}{|c|c|c|c|c|c|}
\hline \multirow[t]{2}{*}{ S.W. } & \multirow{2}{*}{$\begin{array}{c}\text { Mean dead heart } \\
(\%)\end{array}$} & \multicolumn{2}{|c|}{ Temperature $\left({ }^{\circ} \mathrm{C}\right)$} & \multirow{2}{*}{$\begin{array}{c}\text { Relative } \\
\text { humidity (\%) }\end{array}$} & \multirow{2}{*}{$\begin{array}{c}\text { Rainfall } \\
(\mathrm{mm})\end{array}$} \\
\hline & & Maximum & Minimum & & \\
\hline 28 & 0.00 & 31.92 & 26.78 & 64.85 & 46.80 \\
\hline 29 & 2.29 & 35.14 & 28.00 & 55.99 & 0.00 \\
\hline 30 & 4.73 & 30.00 & 26.57 & 70.14 & 51.75 \\
\hline 31 & 4.90 & 28.42 & 25.71 & 75.03 & 80.03 \\
\hline 32 & 9.00 & 28.42 & 24.92 & 73.03 & 125.50 \\
\hline 33 & 28.00 & 31.57 & 26.50 & 67.24 & 0.00 \\
\hline 34 & 2.40 & 27.00 & 25.21 & 75.28 & 218.16 \\
\hline 35 & 15.00 & 28.92 & 24.85 & 74.21 & 101.40 \\
\hline 36 & 10.00 & 30.85 & 25.78 & 64.71 & 7.85 \\
\hline 37 & 5.00 & 31.85 & 26.07 & 66.74 & 21.10 \\
\hline 38 & 1.00 & 30.78 & 23.71 & 61.64 & 4.35 \\
\hline 39 & 0.50 & 33.21 & 21.57 & 53.60 & 0.00 \\
\hline 40 & 0.00 & 33.78 & 20.78 & 56.03 & 0.00 \\
\hline 41 & 0.00 & 31.00 & 18.50 & 55.71 & 0.00 \\
\hline 42 & 0.00 & 29.14 & 17.50 & 53.21 & 3.40 \\
\hline 43 & 0.00 & 27.21 & 14.64 & 53.85 & 0.45 \\
\hline 44 & 0.00 & 28.14 & 14.29 & 52.42 & 0.00 \\
\hline 45 & 0.00 & 27.14 & 13.57 & 61.53 & 0.00 \\
\hline
\end{tabular}

Table.2 Seasonal incidence of stem borer, Chilo partellus (Swinhoe)

\begin{tabular}{|l|l|l|l|l|l|}
\hline S.W. & $\begin{array}{l}\text { Mean dead heart } \\
(\%)\end{array}$ & \multicolumn{2}{|c|}{ Temperature $\left({ }^{\circ} \mathbf{C}\right)$} & $\begin{array}{c}\text { Relative } \\
\text { humidity }(\%)\end{array}$ & $\begin{array}{c}\text { Rainfall } \\
(\mathbf{m m})\end{array}$ \\
\hline $\mathbf{2 8}$ & 0.00 & 31.92 & 26.78 & 64.85 & 46.80 \\
\hline $\mathbf{2 9}$ & 0.00 & 35.14 & 28.00 & 55.99 & 0.00 \\
\hline $\mathbf{3 0}$ & 5.00 & 30.00 & 26.57 & 70.14 & 51.75 \\
\hline 31 & 11.67 & 28.42 & 25.71 & 75.03 & 80.30 \\
\hline 32 & 15.34 & 28.42 & 24.92 & 73.06 & 125.50 \\
\hline 33 & 21.00 & 31.57 & 26.50 & 67.24 & 0.00 \\
\hline 34 & 30.50 & 27.00 & 25.11 & 75.28 & 218.60 \\
\hline 35 & 25.25 & 28.92 & 24.85 & 74.21 & 101.40 \\
\hline 36 & 22.00 & 30.85 & 25.78 & 64.71 & 7.85 \\
\hline 37 & 18.29 & 31.85 & 26.07 & 66.74 & 21.10 \\
\hline 38 & 15.50 & 30.78 & 23.71 & 61.64 & 4.35 \\
\hline 39 & 10.38 & 33.21 & 21.57 & 53.60 & 0.00 \\
\hline 40 & 6.78 & 33.78 & 20.78 & 56.03 & 0.00 \\
\hline 41 & 5.00 & 31.00 & 18.50 & 55.71 & 0.00 \\
\hline $\mathbf{4 2}$ & 3.33 & 29.14 & 17.50 & 53.21 & 3.40 \\
\hline $\mathbf{4 3}$ & 1.50 & 27.21 & 14.64 & 53.85 & 0.45 \\
\hline $\mathbf{4 4}$ & 0.00 & 28.14 & 14.29 & 52.42 & 0.00 \\
\hline $\mathbf{4 5}$ & 0.00 & 27.14 & 13.57 & 61.53 & 0.00 \\
\hline
\end{tabular}


Fig.1 Seasonal incidence of shoot fly during the crop season (July to November, 2012)

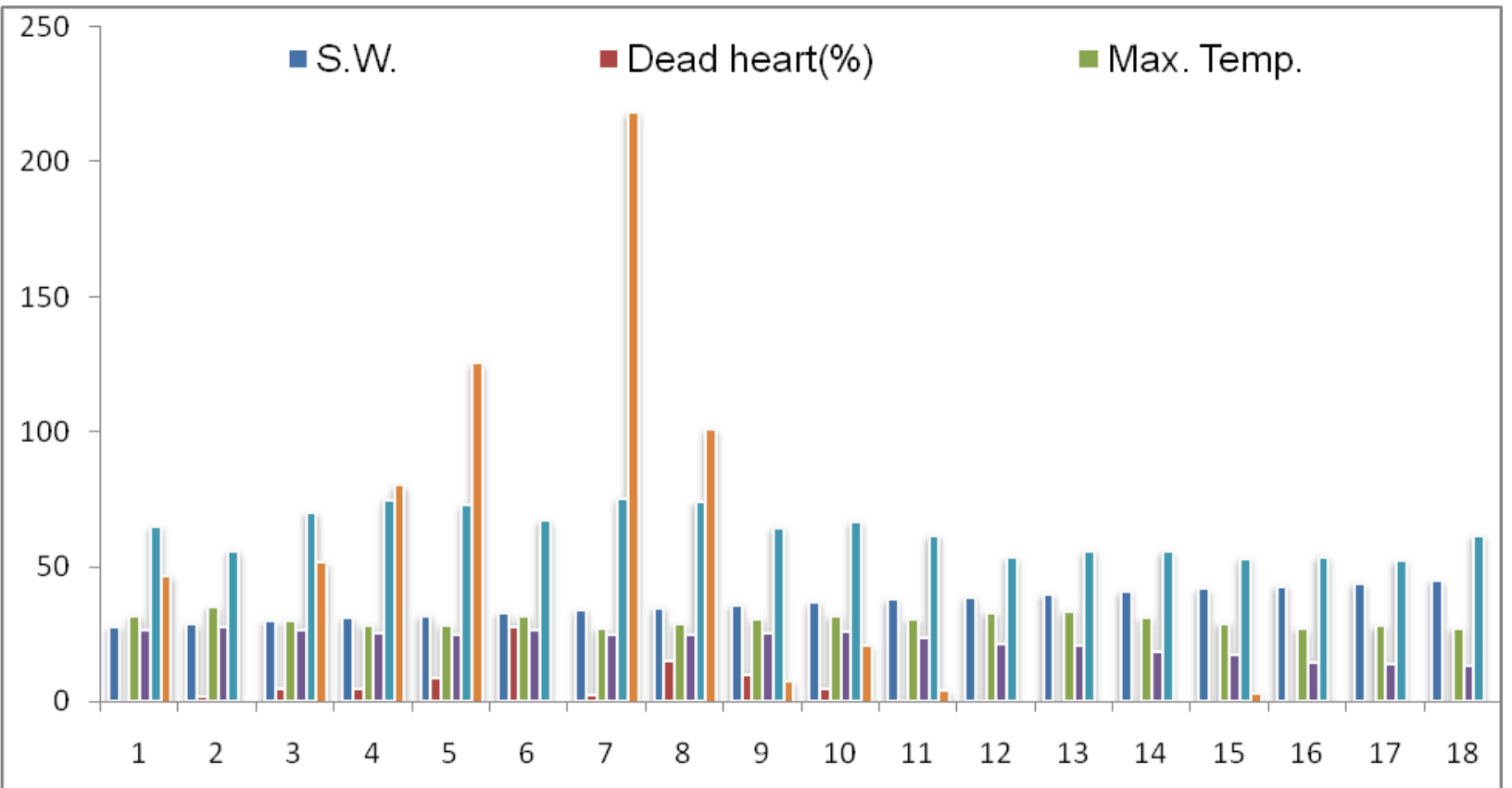

Fig.2 Seasonal incidence of stem borer during crop season (July to November, 2012)

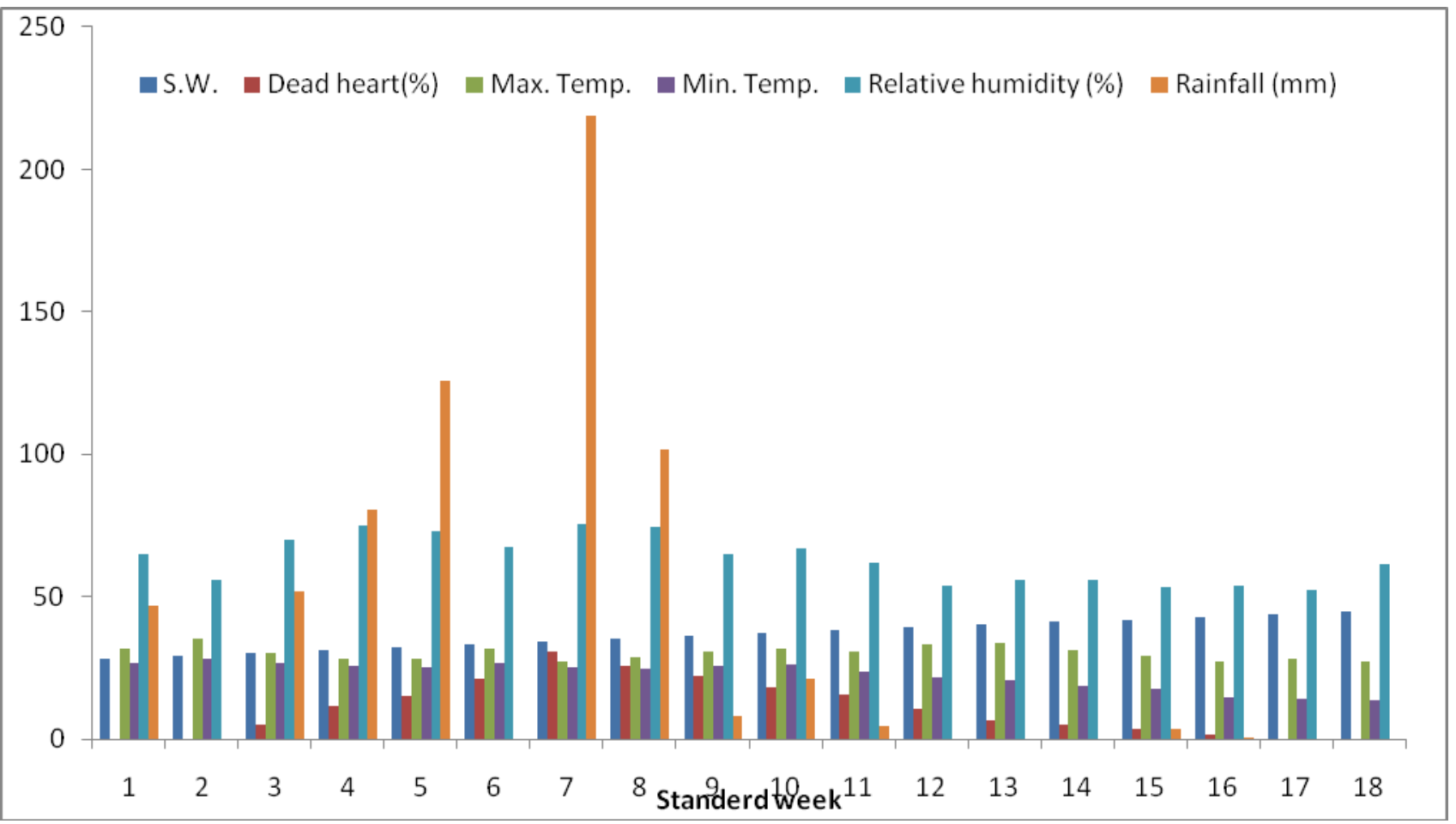

Similarly, Sable et al., (2009) the maximum shoot fly dead hearts recorded were $73.23 \%$ during the $32-37^{\text {th }}$ meteorological week, where maximum and minimum temperature and relative humidity in the morning and evening were 30.00 and $21.8^{\circ} \mathrm{C}$, and 86 and 
$67 \%$, respectively, with $244 \mathrm{~mm}$ rainfall. Karibasavaraja and Balikai (2006) the occurrence of dead heart in the crop was highest on 13-19 August (93.4\%), corresponding to the occurrence of the highest mean number of eggs of the pest per plant (3.20).

\section{Seasonal incidence of stem borer}

Pest population (5\%) observed first during in $30^{\text {th }}$ standard week (July, 23-29) when the maximum and minimum temperature 30.00 and $26.57^{\circ} \mathrm{C}$, respectively, relative humidity 70.14 per cent and rainfall $51.75 \mathrm{~mm}$ were recorded, when the age of the crop was 10 days. The dead hearts increased and reached maximum $(30.50 \%)$ in $34^{\text {th }}$ standard week (Aug, 20-26) when the maximum and minimum temperature 27.00 and $25.21^{\circ} \mathrm{C}$ respectively, relative humidity 75.28 per cent and rainfall $218.6 \mathrm{~mm}$. Initially the larvae feed on the upper surface of whorl leaves leaving the lower surface intact. In Maharashtra, number of stem borer larvae were found to be high in winter sorghum than in kharif sorghum but the average number of pupae, percentage of stem tunnelling and inter nodes attacked were highest only in rainy (kharif) season (Anonymous, 1987). Singh and Sharma (1984) observed 4-45\% infestation of $C$. partellus in sorghum and maize and maximum infestation was observed during August, which declined gradually in Sep. and Oct. Kandalkar (2002) only minimum temperature showed significant and negative correlation. Maximum temperature, morning and evening $\mathrm{RH}$, and rainfall did not influence stem borer incidence significantly.

\section{References}

Anonymous (1987). Sorghum stem borer in India and Southeast Asia. In: Intl. Workshop of Sorghum Stem Borer, at
Patancheru, 17-20 Nov, ICRISAT, India. pp: 19-25.

Blum, A. (1969). Oviposition preference by the sorghum shoot fly, Atherigona soccata in progenies of susceptible $\mathrm{x}$ resistant sorghum crosses. Crop Sci., 2: 695-696.

De Groote HW, Overholt JO, Ouma and Mugo S (2003). Assessing the impact of Bt maize in Kenya using a GIS model. Paper presented at the International Agricultural Economics Conference, Durban, 17th -23rd, August. pp. 78-79.

ICRISAT (1992). The medium term plan. Ann. Progress Report, Vol. II. ICRISAT, AP, India. pp: 312.

Jain, K.K. and Bhatnagar, M. P. (1962). Studies on the varietal resistance to the jowar shoot fly. Indian J. Genet., 22: 224-229.

Jotwani MG, Chaudhari S, Singh SP and Young WR (1971). Studies on resistance in sorghum against stem borer, Chilo zonellus (swin.). Investigations on Insect Pest of Sorghum and Millets.3: 113-118.

Kamatar, M. Y., Salimath, P. M. and Deshpande, V. P. (2001a). Seasonal variation in shoot fly infestation and level of resistance in sorghum at Dharwad. Proceeding of the National symposium on the trends in Evolutionary biology, 1-3 ${ }^{\text {rd }}$ March 2001, Karnatak University, Dharwad, India, $56 \mathrm{pp}$.

Kandalkar, H. G. Men, U. B. Atale, S. B. Kadam, P. S. (2002). Path co-efficient analysis of sorghum shoot fly incidence with climatic factors. Insect Environment, 7 (2): 91-92.

Karibasavaraja, L. R. Balikai, R. A. (2006). Seasonal incidences of sorghum shoot fly and correlations with weather parameters. International Journal of Agricultural Sciences, 2 (2): 381-384. 
Maiti, R. K and Bidinger, F. R. (1979).A simple approach to the identification of shoot fly tolerance in sorghum. Indian J. Pl. Prot., 7: 135-140.

Ponnaiya, B. W. X. (1951). Studies on the genus Sorghum to the insect pest, Atherigona indica. Madars University Journal, 21: 203-217.

Prem Kishore (2001a). Current status of host plant resistance in Sorghum in India. Journal of Entomological Research., 25: $1-20$.

Rai, S. and Jotwani, M. G. (1977). Estimation of losses at various levels of shoot fly infestation. Entomologists Newsletter, 7: $15-16$

Sable, K. R. Kamble, S. K. Changule, R. B. Dhutraj, D. N. (2009). Seasonal incidence and weather correlation of sorghum shoot fly, Atherigona soccata (Rondani). Journal of Maharashtra Agricultural Universities, 34 (2): 243244.

Sharma, H. C. Taneja, S. L., Leuschner, K. and Nwanze, K. F. (1992). Techniques to screen sorghum for resistance to insect pests. ICRISAT Bulletin No. 32: pp 1-2.

Singh J. P and Sharma Y (1984). Incidence of Chilo partellus (Swinhoe) on maize and jowar in Punjab. Punjab University Science, Res. Bull, 34: 105-114.

Songa J. M, Bergvinson D and Mugo S (2001). Impacts of Bt-gene based resistant in maize on non-target organism in Kenya. Characterization of target and non-target organisms of $\mathrm{Bt}$ gene- based resistance in two major maize growing regions in Kenya. Insect resistant maize for Africa (IRMA). Annual Report, 4: 16-21.

Taneja, S. L. and Leuschner, K. (1985). Resistance screening and mechanisms of resistance in sorghum to shoot fly. Proceeding of the International Sorghum Entomology workshop, 15-21 July, 1984.Texas A \& M University, College Station, Texas, USA. pp. 115129.

\section{How to cite this article:}

Nirvesh Singh, Rajendra Singh and Kaushlendra Kumar. 2018. Studies on Seasonal Incidence of Sorghum Shoot Fly, Atherigona soccata (Rondani) and Stem Borer, Chilo partellus (Swinhoe), in Relation to Abiotic Factor. Int.J.Curr.Microbiol.App.Sci. 7(06): 916-921. doi: https://doi.org/10.20546/ijcmas.2018.706.108 